\title{
Я. ЛУТТ
}

удК $551.351(474.2)$

\section{Les.... \\ НЕКОТОРЫЕ ЧЕРТЫ ФОРМИРОВАНИЯ ДОННЫХ ОСАДКОВ ВЯЙНАМЕРИ ПО ДАННЫМ ИХ ГРАНУЛОМЕТРИЧЕСКОГО COCTABA}

Вяйнамери отделено от Балтийского моря крупными островами Западно-Эстонского архипелага (Сааремаа, Хийумаа, Вормси). Площадь его несколько более $2000 \kappa \mu^{2}$, т. е. около $0,6 \%$ общей площади Балтики, средняя глубина $5 \mu$, наибольшая $-23 \mu$.

Осадконакопление в пределах Вяйнамери контролируется гидрометеорологическими (ветры, течения, сгоны-нагоны, ледовый режим) и геолого-геоморфологическими (характер слагающих береговую зону пород, а также морское дно, современные вертикальные движения земной коры, донный рельеф) факторами. Осадочный материал, поступающий в Вяйнамери, в основном распределяется по его дну под действием волн и течений. Несмотря на небольшие размеры водоема, влияние штормового волнения на дно Вяйнамери значительное и охватывает практически всю акваторию. Немаловажное значение имеют при седиментации также поверхностные и придонные морские течения, так как первые служат транспортирующими агентами, а вторые оказывают, кроме того, на дно и эродирующее воздействие. Характер и скорость течений Вяйнамери изучены Х. Мардисте (1964) и поэтому отметим лишь, что при ветре 5-6 баллов скорость поверхностных течений в проливах доходит до $75 \mathrm{~cm} / \mathrm{ce \kappa}$, а скорость придонных течений - до $57 \mathrm{~cm} /$ сек.

Гранулометрия осадков Вяйнамери изучена в 726 пробах (табл. 1). При выделении типов осадков использована классификация Института океанологии АН СССР (Безруков, Лисицын, 1960), где в качестве основных показателей гранулометрического состава приняты содержание преобладающей фракции и средний диаметр $\left(M_{d}\right)$ частиц.

Большое влияние на распределение осадочного материала по крупности по дну Вяйнамери оказывает донный рельеф, который местами очень расчленен. На участках с более выровненным рельефом, к которым относятся плес Кассари-лахт на западе Вяйнамери и центральная часть водоема глубиной $7-9$ м, распространяются гранулометрические однообразные осадки. К этим участкам приурочены хорошо сортированные крупные алевриты, содержащие обычно 60-80\% частиц размерностью $0,1-0,05$ м.. Основными примесями встречаются здесь мелкопесчаные $(0,25-0,1$ мм) и мелкоалевритовые $(0,05-0,01$ мм) частицы, роль более крупного и мелкого материала весьма скромная. Сравнительно мало расчленен донный рельеф и в пределах проливов Вяйке-Вяйн (между о-вами Сааремаа и Муху) и Суур-Вяйн (между о. Муху и материком), где также доминируют хорошо сортированные крупные алевриты (Lutt, 1979).

3 ENSV TA Toimetised. G 21980 
Гранулометрический состав

\begin{tabular}{|c|c|c|c|c|c|c|c|c|c|}
\hline \multirow{2}{*}{$\underset{\text { мм }}{\Phi \text { ракцин, }}$} & \multicolumn{3}{|c|}{$\begin{array}{c}\text { Галечно-гравийные } \\
\text { осадки }\end{array}$} & \multicolumn{3}{|c|}{ Крупные пески } & \multicolumn{3}{|c|}{ Среднне пески } \\
\hline & $\begin{array}{l}\text { Чис- } \\
\text { ло } \\
\text { проб }\end{array}$ & $\begin{array}{c}\text { Предел } \\
\text { колебання }\end{array}$ & Среднее & $\begin{array}{l}\text { Чнс- } \\
\text { ло } \\
\text { проб }\end{array}$ & $\begin{array}{c}\text { Предел } \\
\text { колебания }\end{array}$ & Среднее & $\begin{array}{l}\text { Чис- } \\
\text { ло } \\
\text { проб }\end{array}$ & $\begin{array}{c}\text { Предел } \\
\text { колебания }\end{array}$ & Среднее \\
\hline$>10$ & 6 & $8,86-51,31$ & 16,25 & 9 & $0-9,14$ & 2,25 & 33 & $0-12,93$ & 1,39 \\
\hline $10-5$ & 9 & $1,37-35,46$ & 17,06 & 19 & $0-11,29$ & 2,28 & 52 & $0-15,46$ & 1,91 \\
\hline $5-2,5$ & 9 & $2,51-13,24$ & 7,88 & 19 & $0,01-12,52$ & 2,29 & 52 & $0-10,16$ & 1,54 \\
\hline $2,5-1,0$ & 10 & $4,50-53,31$ & 18,13 & 21 & $0,88-37,54$ & 12,68 & 60 & $0,08-21,71$ & 6.70 \\
\hline $1,0-0,5$ & 10 & $3,67-40,27$ & 13,50 & 21 & $21,62-76,72$ & 42,66 & 60 & $0,24-35,42$ & 14,17 \\
\hline $0,5-0,25$ & 10 & $2,10-18,00$ & 10,65 & 21 & $6,90-33,78$ & 20,18 & 60 & $20,35-66,27$ & 39,69 \\
\hline $0,25-0,1$ & 10 & $0,12-18,23$ & 5,20 & 21 & $0,70-20,14$ & 7,19 & 60 & $1,81-44,63$ & 16,92 \\
\hline $0,1-0,05$ & 10 & $0,05-20,14$ & 4,61 & 21 & $0,04-35,73$ & 7,46 & 60 & $0,17-28,82$ & 10,42 \\
\hline $0,05-0,01$ & 10 & $0,02-7,29$ & 2,24 & & & & 60 & $0,05-13,63$ & 2,37 \\
\hline $\begin{array}{l}<0,01 \\
0.01-0,005\end{array}$ & 10 & $0,25-16,94$ & 4,48 & 21 & $0,16-11,54$ & 3,01 & 60 & $0,09-28,36$ & 4,89 \\
\hline $0,005-0,001$ & & & & & & & & & \\
\hline$<0,001$ & & 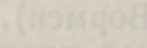 & & & & & & $\cos ^{2}$ & \\
\hline$M_{d}$ & 10 & $0,26-10,05$ & 2,94 & 21 & $0,29-0,90$ & 0,61 & 60 & $0,16-0,73$ & 0,34 \\
\hline$S_{0}{ }^{a}$ & 5 & $1,31-9,10$ & 4,32 & 21 & $1,24-3,66$ & 1,95 & 60 & $1,17-7,07$ & 2,02 \\
\hline
\end{tabular}

* Сумма фракций более 1,0 мм. ** Сумма фракций более 0,1 мм.

Для остальных частей Вяйнамери характерен более или менее сложный рельеф дна, что сказывается и на распределении осадочного материала в пределах этих участков, расположенных преимущественно западнее о. Вормси и вдоль материка с севера на юг, где много островков и подводных мелей. Очень изменчив рельеф дна юго-восточнее о. Муху, где отмечаются возвышения относительной высотой 5-7 . Расчлененность донного рельефа обусловливает на этих участках разнообразие осадочного материала и его мозаичное распределение (Lutt, 1979). В этой части акватории часты и выходы более древних (плейстоценовых) отложений в виде морен и ленточных глин, которые обычно покрыты маломощным (до 5 cм) слоем остаточных продуктов размыва (валунов, гальки, гравия, крупного и среднего песка).

Анализ распределения гранулометрических фракций осадочного материала на дне Вяйнамери дает достаточно полное представление о локализации и изменчивости осадков в пределах этой акватории, а также о характере осадконакопления здесь. Для этого были составлены схемы распространения следующих размерных фракций: грубообломочных (рис. 1), крупно-среднепесчаных (рис. 2), мелкопесчаных (рис. 3), крупноалевритовых (рис. 4), мелкоалевритовых (рис. 5) и пелитовых (рис, 6).

Общий характер распределения грубообломочного материала выявляется на схеме (рис. 1) довольно четко: максимальные его концентрации связаны непосредственно с участками размыва морен у берега, где глубина воды не превышает $2-5 \mu$. По мере удаления от этих участков и с увеличением глубины количество галечно-гравийного материала сравнительно быстро уменьшается. На фоне общего уменьшения грубообломочного материала при удалении от участков размыва морен в сторону бо́льших глубин особенно резко уменьшается содержание галечной фракции (более 10 мм), количество которой непосредственно на выходах морен доходит до $31-51 \%$ (табл. 1). Повышенное содержание грубообломочного материала (более $25 \%$ ) отмечается также на 


\section{донных осадков Вяйнамери}

\begin{tabular}{|c|c|c|c|c|c|c|c|c|c|c|c|}
\hline \multicolumn{3}{|c|}{ Мелкие пески } & \multicolumn{3}{|c|}{ Крупные алевриты } & \multicolumn{3}{|c|}{ Мелкне алевриты } & \multicolumn{3}{|c|}{$\begin{array}{c}\text { Алевритово-пелитовые } \\
\text { илы }\end{array}$} \\
\hline $\begin{array}{l}\text { Чис- } \\
\text { ло } \\
\text { проб }\end{array}$ & $\begin{array}{c}\text { Предел } \\
\text { колебания }\end{array}$ & $\begin{array}{c}\text { Сред- } \\
\text { нее }\end{array}$ & $\begin{array}{l}\text { Чис- } \\
\text { ло } \\
\text { проб }\end{array}$ & $\begin{array}{c}\text { Предел } \\
\text { колебания }\end{array}$ & $\begin{array}{c}\text { Сред- } \\
\text { нее }\end{array}$ & $\begin{array}{l}\text { Чнс- } \\
\text { ло } \\
\text { проб }\end{array}$ & $\begin{array}{c}\text { Предел } \\
\text { колебання }\end{array}$ & Среднее & $\begin{array}{l}\text { Чис- } \\
\text { ло } \\
\text { проб }\end{array}$ & $\begin{array}{c}\text { Предел } \\
\text { колебания }\end{array}$ & Среднее \\
\hline
\end{tabular}

$\begin{array}{rrrrrr}154 & 0,01-26,46 & 4,75^{*} & 392 & 0-29,42 & 1,18 \\ 155 & 0,01-24,16 & 5,13 & 392 & 0-17,18 & 0,97 \\ 155 & 0,15-45,30 & 12,18 & 392 & 0-23,76 & 2,07 \\ 155 & 19,44-96,30 & 52,81 & 392 & 0,37-47,40 & 11,01 \\ 155 & 0,75-47,79 & 16,99 & 392 & 26,70-92,5 & 61,16 \\ 155 & 0,02-12,11 & 2,80 & 392 & 0,49-41,77 & 13,01 \\ 155 & 0,01-24,78 & 5,34 & 392 & 0,37-47,89 & 10,60\end{array}$

$155 \quad 0,095-0,28$

$155 \quad 1,09-4,67$
$0,17 \quad 392 \quad 0,014-0,20$

$1,64 \quad 392 \quad 1,07-4,72$ $\begin{array}{llc}0,074 & 62 & 0,012-0,048 \\ 1,62 & 58 & 1,42-7,76\end{array}$

$\begin{array}{rrr}2,74^{* *} & 26 & 0,14-17,32 \\ 25,49 & 26 & 2,22-24,70 \\ 43,80 & 26 & 13,33-44,06 \\ 27,97 & 26 & 47,31-68,37 \\ 7,18 & 19 & 1,93-17,50 \\ 9,93 & 19 & 11,17-43,13 \\ 10,96 & 19 & 8,22-41,78 \\ & & \\ 0,030 & 21 & 0,032-0,014 \\ 2,78 & 18 & 3,37-7,44\end{array}$

$5,18^{\text {** }}$

12,47

25,55

56,80

9,36

24,24

23,20

5,05

ленточных глинах, однако здесь обычно преобладают гравийные зерна. Вероятно, этот материал происходит главным образом из морских осадков, которые покрывали ленточные глины при более высоких уровнях моря, но в ходе современного поднятия земной коры, следствием чего является обмеление, оказались размыты. Повышенные содержания грубообломочного материала связаны с ареалами крупныхсредних песков. Лишь в единичных пробах мелкого песка и крупного алеврита количество грубообломочного материала превышает $20 \%$. Мелкозернистые осадки (начиная с мелкого песка) содержат обычно менее $5 \%$ грубообломочного материала, иногда он отсутствует в них полностью (табл. 1). Присутствие примеси грубообломочного материала в составе мелкозернистых осадков связано не с гидродинамикой, а скорее всего с ледовым транспортом.

Итак, грубообломочный материал распространен преимущественно в пределах подводного берегового склона, особенно на участках размыва морен в виде остаточных продуктов абразии последних.

Распределение песчаного материала изображено на двух схемах (рис. 2 и 3). Поскольку гидродинамические свойства и закономерности распространения фракций крупного $(1,0-0,5$ мм) и среднего $(0,5-$ 0,25 мм) песка близки (Лисицын, 1966), распределение их показано на одной схеме (рис. 2). Крупно-среднепесчаный материал в осадках Вяйнамери распространен шире, чем грубообломочный. Его повышенные содержания прослеживаются обычно на выходах ленточных глин (глубже 5 м) (рис. 1 и 2). В этих случаях концентрации крупно-среднепесчаного материала являются также остаточным продуктом размыва. Высокие содержания (более $75 \%$ ) крупно-среднепесчаного материала отмечены также в восточной части Вяйнамери в районе о. Руккираху на глубинах до 5-6 м, где они связаны с размывом флювиогляциальных песков. Повышенные содержания фракции крупного и среднего песка $1,0-0,25$ мм (более $25 \%$ ) наблюдаются также в проливах ВоозиКурк, Хари-Курк и в южной части пролива Суур-Вяйн (рис. 2), где глубина моря обычно более 10 м. На этих участках преимущественно 


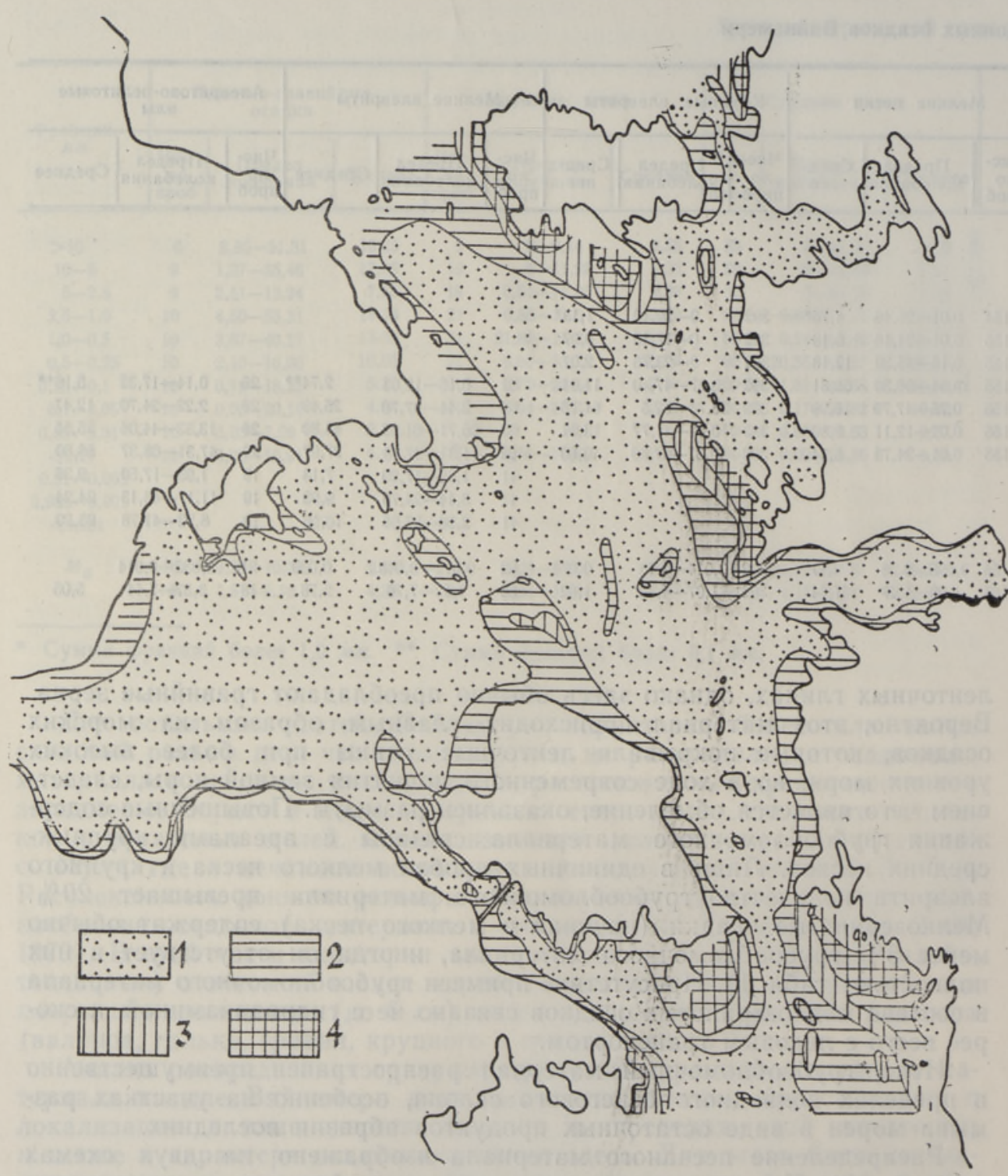

Рис. 1. Схема распространения грубообломочного материала в осадках Вяйнамери. 1 - менее $10 \%, 2-10-25 \%, 3-25-50 \%, 4-$ более $50 \%$.

песчаные осадки мощностью до 10 см покрывают ленточные глины. Судя по гранулометрическому составу осадков, движение водных масс в этих участках Вяйнамери наиболее активное, поскольку они открыты более мощному волнению Балтийского моря и Рижского залива. Кроме того, в пределах этих проливов наблюдаются наиболее сильные течения (Мардисте, 1964), влияние которых обусловливает здесь вынос более мелких частиц.

Более чем $25 \%$-ное содержание крупно-среднепесчаного материала характерно также для подводного берегового склона, где в настоящее время размываются главным образом ленточные глины. Вполне вероятно, что основное количество крупно-среднепесчаного материала явля- 


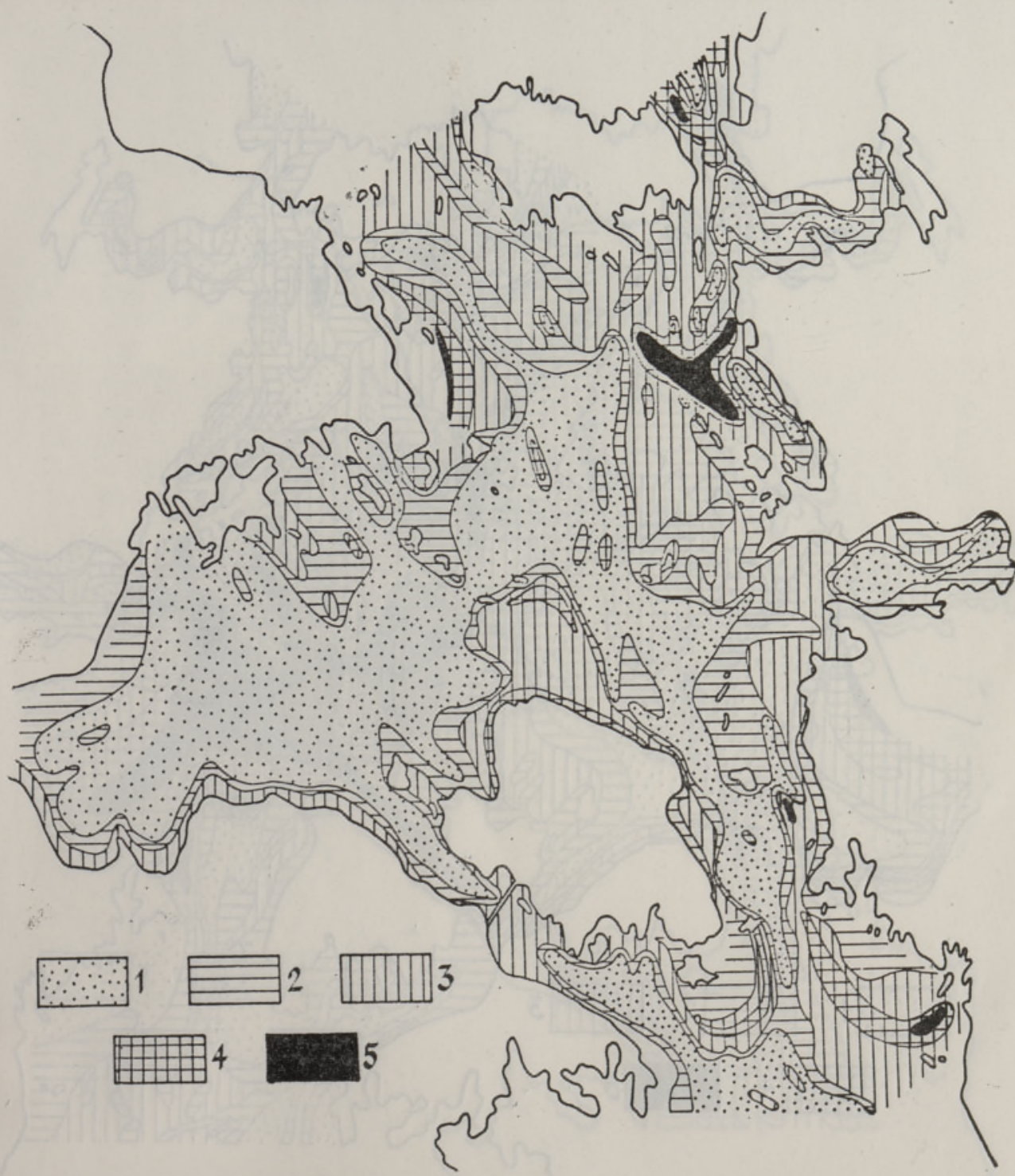

Рис. 2. Схема распространення крупно-среднепесчаного материала $(1,0-0,5$ мм $)$ в осадках Вяйнамери. 1 - менее $10 \%, 2-10-25 \%, 3-25-50 \%, 4-50-70 \%, 5-$ более $70 \%$.

ется продуктом перемыва морских осадков, покрывавших ленточные глины при более высоком уровне моря. Таким образом, крупно-среднепесчаный материал генетически связан с грубообломочным, а его распределение в настоящее время в основном обусловлено размывом плейстоценовых отложений.

Более мелкозернистые осадки содержат обычно немного крупносреднепесчаных частиц, но иногда их содержание в современных мелких песках может достигать 45-46\%. Алевритовые и пелитовые осадки характеризуются самыми низкими содержаниями (обычно менее 10\%) крупно-среднепесчаных частиц, 


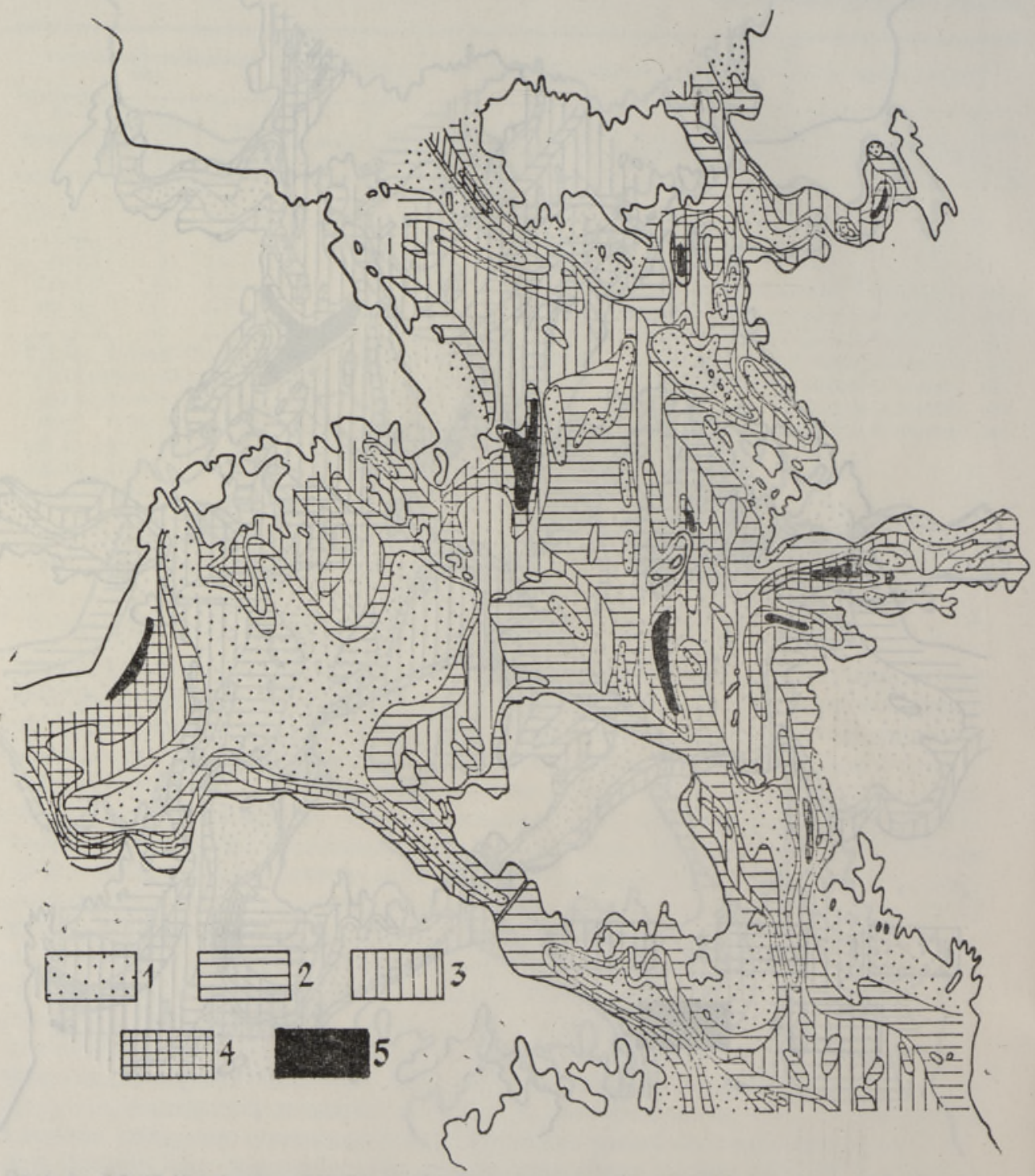

Рис. 3. Схема распространения мелкопесчаного материала $(0,25-0,1$ мм $)$ в осадках Вяйнамери. 1 - менее $10 \%, 2-10-25 \%, 3-25-50 \%, 4-50-70 \%, 5-$ более $70 \%$.

Как видно из схемы распределения мелкопесчаной фракции (рис. 3), содержание ее в донных осадках довольно высокое, нередко более $25 \%$, а местами доходит до $96,3 \%$ (табл. 1). Высокие содержания (более $50 \%$ ) мелкопесчаного материала встречаются чаще, чем высокие содержания крупно-среднепесчаных фракций. Как неоднократно указывалось в литературе (Лисицын, 1966 и др.), наиболее чувствительными к динамическому воздействию являются частицы размерностью от 0,18 мм, входящие во фракцию мелкого песка. Они легко переоткладываются, так как сцепление между ними слабое, и в результате мелкопесчаный материал обычно (но не всегда) оказывается хорошо сортированным и состоит почти исключительно из зерен этой размерности. 


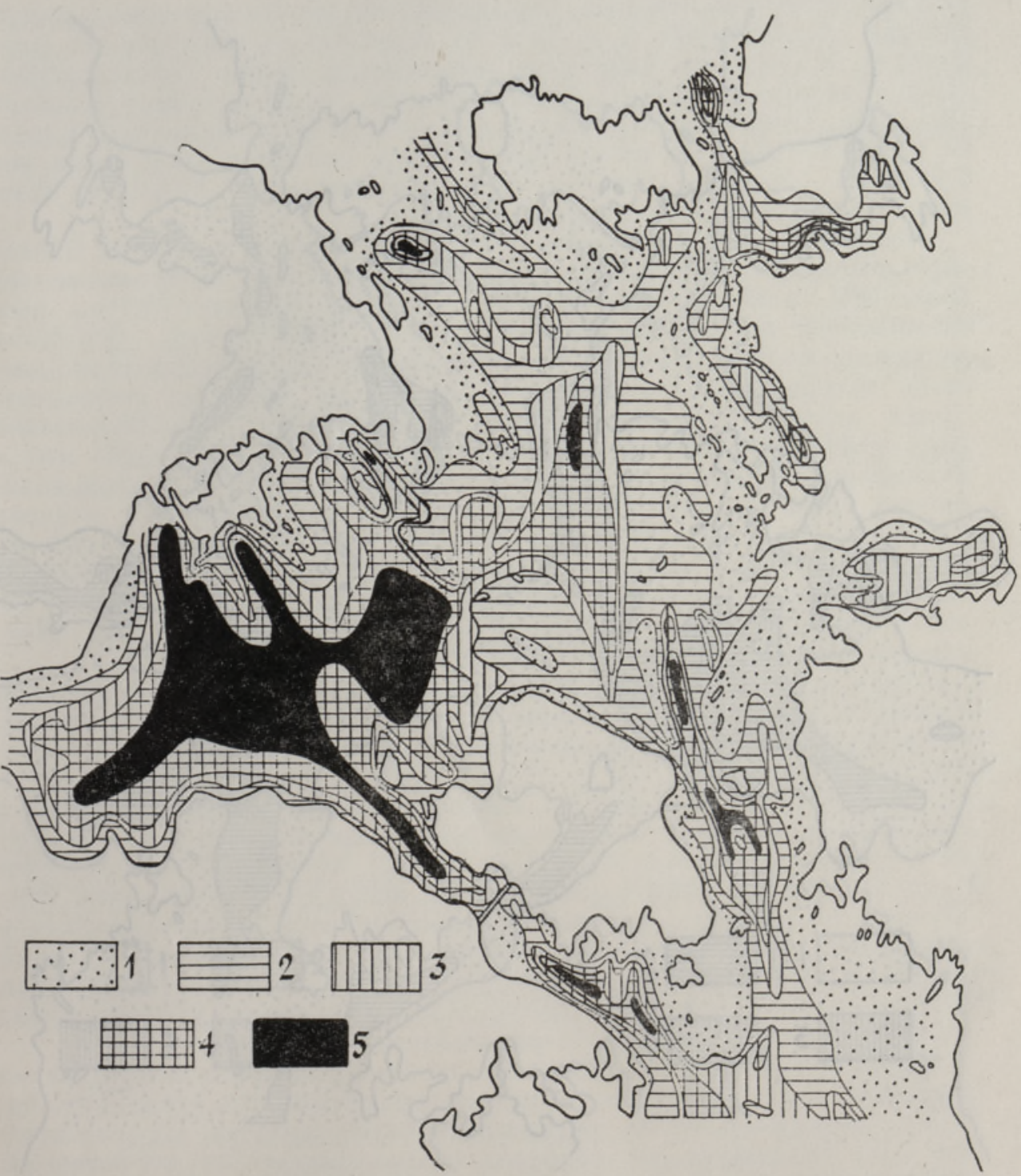

Рнс. 4. Схема распространения крупноалевритового материала $(0,1-0,05$ мм $)$ в осадках Вяйнамери. 1 - менее $10 \%, 2-10-25 \%, 3-25-50 \%, 4-50-70 \%, 5-$ более $70 \%$.

Интересно отметить, что в мелкопесчаной фракции, как правило, преобладают зерна размерностью $0,2-0,16$ мм, содержание которых в осадке может доходить до $60 \%$. Количество более крупных $(0,25-$ 0,2 мм) и мелких $(0,16-0,1$ мм) зерен значительно меньше. Следовательно, возникают зоны с повышенным содержанием мелкопесчаного материала (более $50 \%$ ), в основном благодаря концентрации зерен размерностью $0,2-0,16$ мм. В пределах Вяйнамери такие зоны прослеживаются, как правило, неширокими полосами (рис. 3), приуроченными к нижней части подводного берегового склона, где глубина моря 5-7 $м$, В сторону береговой линии, а также мористее количество зерен 


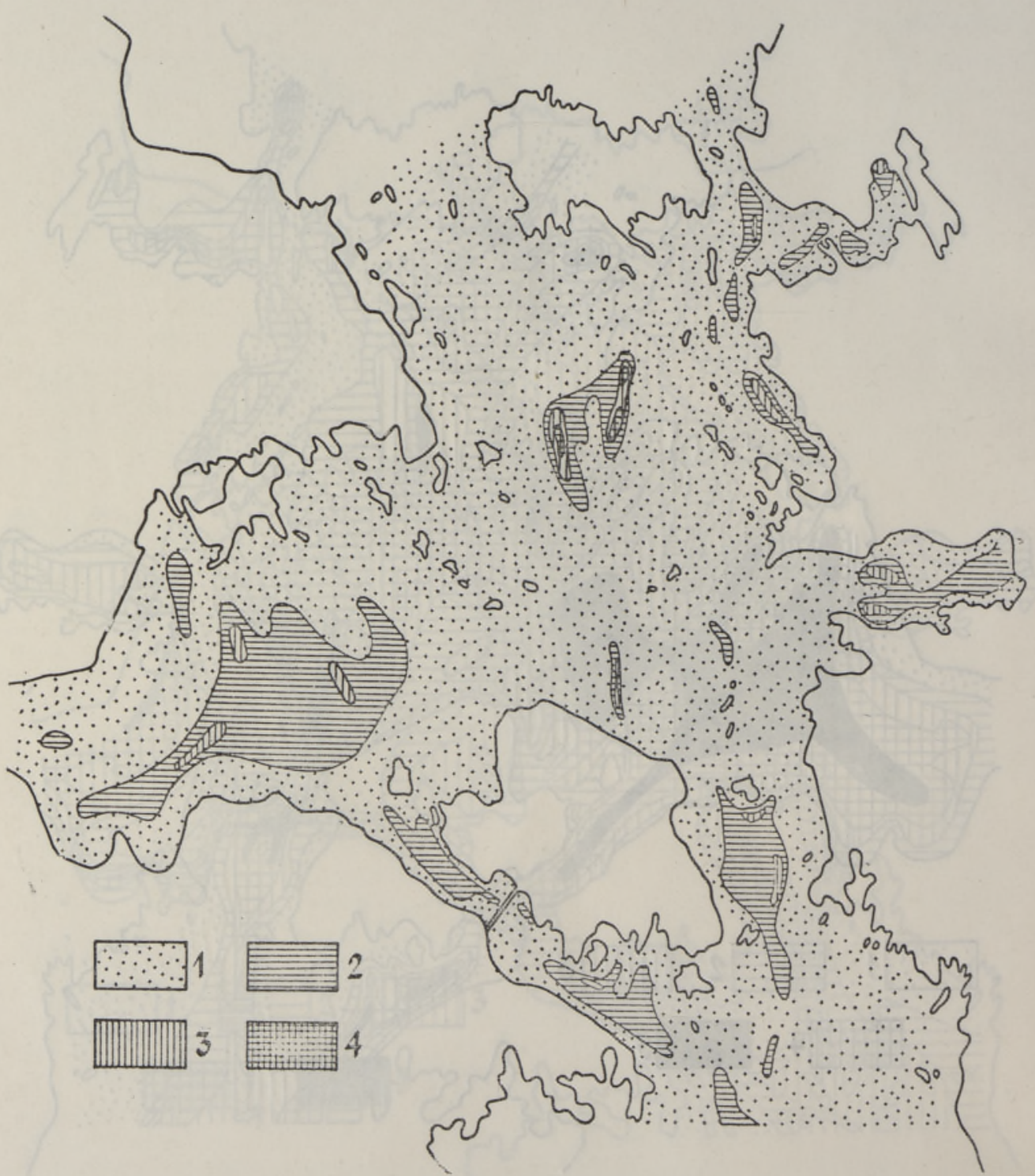

Рис. 5. Схема распространения мелкоалевритового материала $(0,05-0,01$ мм) в осадках Вяйнамери. 1 - менее $10 \%, 2-10-25 \%, 3-25-50 \%, 4-$ более $50 \%$.

размерностью $0,25-0,1$ мм постепенно уменьшается. Одинаково мало (обычно менее 10\%) содержится мелкопесчаного материала в алевритах-пелитах и крупнообломочных осадках.

Крупноалевритовый материал $(0,1-0,05$ мм) в пределах Вяйнамери распространен наиболее широко. Его высокие содержания (более $50 \%$ ) характерны для глубоководных частей водоема и прослеживаются также в мелководных заливах, защищенных от сильного волнения (рис. 4). Они занимают значительные пространства на плесе Кассарилахт, центральные части проливов Суур- и Вяйке-Вяйн, центральную часть Вяйнамери, а также среднюю часть залива Хаапсалу. Высокие содержания крупноалевритового материала небольшими пятнами на- 


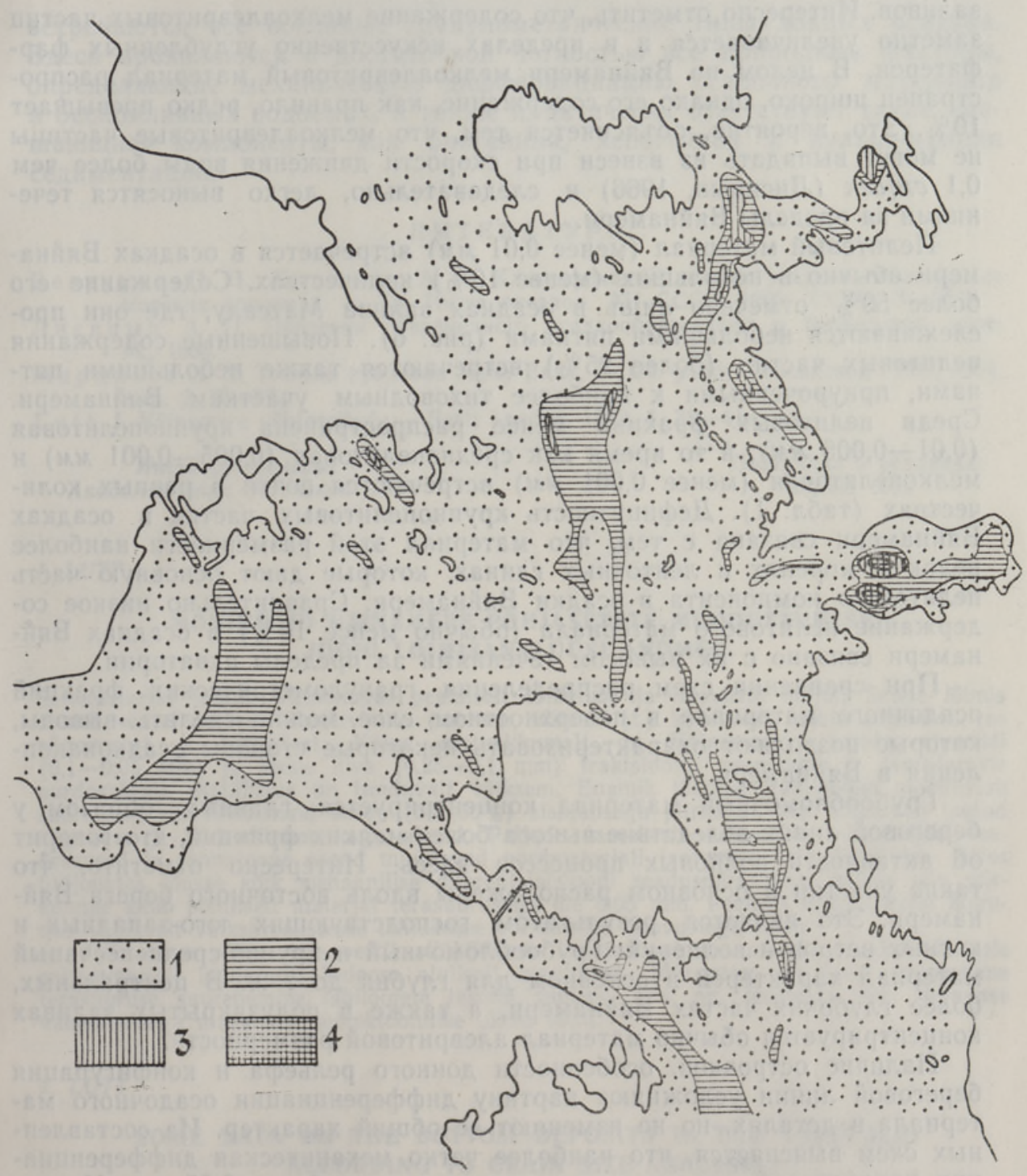

Рнс. 6. Схема распространения пелитового материала (менее 0,01 мм) в осадках Вяйнамери. 1 - менее $10 \%, 2-10-25 \%, 3-25-50 \%, 4-$ более $50 \%$.

блюдаются и в других частях Вяйнамери. Минимальные содержания крупноалевритовой фракции (менее 5\%) прослеживаются в прибрежной зоне, где в основном распространяются грубые осадки.

Сравнивая схемы распределения крупного и мелкого алеврита (рис. 4 и 5), выясняется довольно низкое содержание последнего даже в зонах его максимального накопления. Максимальное содержание мелкоалевритового материала редко превышает $50 \%$. Такие концентрации встречаются отдельными небольшими пятнами (рис. 5) в центральной части Вяйнамери. Повышенные содержания мелкого алеврита (более $25 \%$ ) прослеживаются в осадках средней части плеса Кассарилахт, а также в осадках других защищенных от сильного волнения 
заливов. Интересно отметить, что содержание мелкоалевритовых частиц заметно увеличивается и в пределах искусственно углубленных фарфатеров. В целом по Вяйнамери мелкоалевритовый материал распространен широко, однако его содержание, как правило, редко превышает $10 \%$. Это, вероятно, объясняется тем, что мелкоалевритовые частицы не могут выпадать из взвеси при скорости движения воды более чем 0,1 см/сек (Лисицын, 1966) и, следовательно, легко выносятся течениями за пределы Вяйнамери.

Пелитовый материал (менее 0,01 мм) встречается в осадках Вяйнамери обычно в небольших (менее 10\%) количествах. Содержание его более $50 \%$ отмечено лишь в осадках залива Матсалу, где они прослеживаются небольшими пятнами (рис. 6). Повышенные содержания пелитовых частиц (более $25 \%$ ) встречаются также небольшими пятнами, приуроченными к наиболее тиховодным участкам Вяйнамери. Среди пелитовых фракций менее распространена крупнопелитовая $(0,01-0,005 м \mu)$, в то время как среднепелитовая $(0,005-0,001$ мм $)$ и мелкопелитовая (менее 0,001 мм) встречаются почти в равных количествах (табл. 1). Дефицитность крупнопелитовых частиц в осадках Вяйнамери связана с тем, что материал этой размерности наиболее редок в моренах и ленточных глинах, которые дают основную часть пелитового компонента в осадки Вяйнамери. Сравнительно низкое содержание пелитового материала (обычно менее 10\%) в осадках Вяйнамери связано с их выносом течениями за пределы акватории.

При сравнении схем распределения гранулометрических фракций осадочного материала в поверхностном слое можно сделать выводы, которые позволяют охарактеризовать некоторые стороны осадконакопления в Вяйнамери.

Грубообломочный материал концентрируется главным образом у береговой линии вследствие выноса более мелких фракций, что говорит об активности волновых процессов здесь. Интересно отметить, что такие участки в основном расположены вдоль восточного берега Вяйнамери. Это является результатом господствующих юго-западных и южных ветров и волнений. Грубообломочный и крупно-среднепесчаный материал характерен в основном для глубин до 7 м. В центральных, более глубоких частях Вяйнамери, а также в полузакрытых заливах концентрируется обычно материал алевритовой размерности.

Наличие островков, особенности донного рельефа и конфигурация береговой линии усложняют картину дифференциации осадочного материала в деталях, но не изменяют ее общий характер. Из составленных схем выясняется, что наиболее четко механическая дифференциация проявляется для материала размерностью более 0,05 мм. Мелкоалевритовая и пелитовая фракции характерны в основном для затишных зон. Изучение вертикальных разрезов донных осадков показывает, что характер механического осадконакопления в пределах Вяйнамери во времени существенно не изменился. Отмечается некоторое изменение (уменьшение $M_{d}$ ) осадочного материала вниз по разрезу, что связано c постоянным обмелением Вяйнамери вследствии поднятия земной коры. Основная масса исходного вещества морских осадков, происходящего из плейстоценовых отложений и палеозойских пород, распределяется по дну водоема в соответствии с гидродинамической обстановкой, а некоторая часть тонких фракций (менее 0,05 мм) выносится течениями за пределы бассейна. Этим объясняется и относительно скромная доля частиц размерностью менее 0,05 мм, которые в моренах и ленточных глинах весьма широко распространены.

Таким образом, в Вяйнамери на сравнительно несбольшой площади 
встречаются все основные гранулометрические типы донных осадков. Здесь проявляются с достаточной четкостью все природные факторы, определяющие механическую дифференциацию осадочного материала в бесприливных водоемах, а также практически отсутствуют такие «мешающие» компоненты, как биогенная, хепогенная и вулканогенная седиментации.

\section{ЛИТ Е Р А Т У Р А}

Без руков П. Л., Л и с и цын А. П. Классификация донных осадков современных морских водоемов. - Тр. Ин-та океанол. АН СССР, 1960, XXXII, 3-14.

Л и с и цын А. П. Процессы современного осадкообразования в Беринговом море. M., 1966.

М а рди сте Х. Х. Течение проливов Муху-Вяйн. - Сб. работ Таллинской ГМО, 1964, вып. 2, 70-87.

L u t t, J. Väinamere pōhjasetted. - Eesti Loodus, 1979, 1, 38-41.

Институт геологии

Академии наук Эстонской ССР
Поступила в редакцию 20/XII 1979

\section{J. LUTT}

\section{MONINGAID VÄINAMERE POHJASETETE MOODUSTUMISE JOONI LÕIMISANALUOSI ANDMEIL}

Settematerjal jaotub Väinameres peamiselt lainetuse ja hoovuste mōjul. Setete lõimis oleneb suurel määral lähtekivimite (moreen, viirsavi jt.) koostisest, pöhja reljeefist, vee sügavusest jt. teguritest. Kõige ulatuslikumalt on Väinameres jämeda aleuriidi $(0,1-0,05 \mathrm{~mm})$ ja peene liiva $(0,25-0,1 \mathrm{~mm})$ fraktsioone; peenemate ja jämedamate purdosakeste osatähtsus on tunduvalt väiksem. Enamik löimise fraktsioone moodustab suuremaid või väiksemaid kōrge (üle $50 \%$ ) sisaldusega piirkondi, mis hõlmavad teatud sügavuse ja hüdrodünaamikaga alasid. Paljude saarekeste esinemine, pöhjareljeefi iseärasused ja rannajoone asend muudavad purdmaterjali jaotumist vaid detailides, jättes üldjoontes jõusse kõik mehaanilise diferentsiatsiooni seaduspärasused, millele siin piirkonnas allub põhiliselt materjal terasuurusega üle $0,05 \mathrm{~mm}$. Peenem settematerjal koguneb valdavalt vaikseveelistesse lahtedesse vổ kandub hoovustega välja.

Väinamere põhjasetete vertikaalläbilõigete tundmaõppimine näitab, et ajaliselt pole settematerjali kuhjumise iseloom oluliselt muutunud. Märgatav on vaid mõningane terasuuruse suurenemine läbilõigete lasumi suunas, mis on seostatav vee sügavuse vähenemisega makoore neotektoonilise tõusu tõttu.

\section{J. LUTT}

\section{SOME DATA ON THE BOTTOM DEPOSITS IN THE VAINAMERI ACCORDING TO GRAIN SIZE ANALYSIS}

In the Väinameri, the bottom deposits are mainly distributed due to the motion of the waves and currents. Their formation depends to a great extent on the composition of the initial deposits (till, varved clay, etc.), on the topography of the bottom, depth of water, and other factors. Of the greatest distribution are here the coarse fractions of silt $(0.1-0.05 \mathrm{~mm})$ and fine sand $(0.25-0.1 \mathrm{~mm})$; the value of the finer or coarser fractions is of a much lesser importance. The majority of grain size fractions are distributed in smaller or bigger localities where their content is rather high $(>50 \%)$, and which occupy areas of a certain depth and certain dynamics. The occurrence of numerous islets, the peculiarities of the bottom topography, and the shorelines affect the distribution of the fractions in details only, leaving the general regularities in the mechanical differentiation of the material intact; those regularities mainly concern the material of the grain size $>0.05 \mathrm{~mm}$. The finer bottom deposits are often accumulated in calm-water baylets, or are carried farther away by currents.

The investigation of the vertical cross-sections of the bottom deposits in the Väinameri shows that the nature of sedimentation here has not considerably changed in time. In the vertical sequence one may notice a slight increase in the grain size towards the uppermost part; this may be connected with a shallowing of the water due to neotectonic movements of the Earth's crust. 